\title{
Penerapan Wireless Distribution System (WDS) Mesh Untuk Optimasi Coverage Area Wifi Universitas Muhammadiyah Jember
}

\author{
Achmad Riyadus Sholikhin ${ }^{1)}$, Taufiq Timur Warisaji ${ }^{2)}$, Triawan Adi Cahyanto ${ }^{\text {3) }}$ \\ 1,2,3) Jurusan Teknik Informatika, Fakultas Teknik, Universitas Muhammadiyah Jember \\ Email: ${ }^{1)}$ riyadus.93@gmail.com, ${ }^{2)}$ taufiqtimur@unmuhjember.ac.id, ${ }^{3)}$ triawanac@unmuhjember.ac.id
}

\begin{abstract}
Abstrak : Salah satu perubahan yang sangat pesat di dalam jaringan komputer adalah penggunaan wireless LAN (WLAN) untuk mengakses jaringan baik lokal maupun internet. Salah satu cara penambahan Access Point (AP) yang tidak mengubah konfigurasi software yang telah di gunakan yaitu menggunakan jaringan Wireless Distribution System Mesh (WDS). Penggunaan WDS mesh di Universitas Muhammmadiyah Jember memungkinkan konfigurasi wireless yang sedikit berbeda agar dapat mengurangi terputusnya koneksi pada pengguna karena jangkauan area jaringan wireless. Salah satu langkah adalah dengan menggunakan beberapa perangkat Acesss Point menjadi satu kesatuan untuk menangani kasus terputusnya koneksi dengan memanfaatkan service jaringan yaitu WDS Mesh. Wireless Distribution System atau (WDS) Mesh mampu mengcoverage area wifi di Universitas Muhammadiyah Jember dan hasil ujicoba serta analisa device client terhadap AP yang sudah di WDS Mesh dengan parameter Signal Strength, CCQ, Signal to Noise, Throughput adalah Excellent (Bagus).
\end{abstract}

Kata kunci: Wireless Distribution System (WDS) Mesh, Access Point, Wireless Network.

\section{PENDAHULUAN}

Salah satu perubahan yang sangat pesat di dalam jaringan komputer adalah penggunaan wireless LAN (WLAN), kemudahan-kemudahan penggunaan yang di tawarkan menjadi daya tarik tersendiri bagi pengguna komputer untuk mengakses suatu jaringan dan internet (Cahyanto, 2011). Masalah yang akan dihadapi apabila menerapkan jaringan wireless LAN salah satunya adalah masalah cakupan area hotspot dan koneksi antar Access Point. Hotspot memiliki cakupan area tertentu tergantung pada spesifikasi peralatan Access Point (AP) yang digunakan. Untuk memperluas area yang akan di cakup, perlu penambahan Access Point (AP) lagi (Markhadam, 2016). Penambahan Access Point (AP) ini diharapkan tidak mengubah konfigurasi software yang telah di gunakan dan bisa digunakan sebagai sarana untuk roaming bagi pengguna layanan (Putra \& KH, 2011). Salah satu cara penambahan Access Point (AP) serta tidak merubah konfigurasi software yang sudah telah di gunakan yaitu menggunakan jaringan Wireless Distribution System mesh (WDS). WDS mesh memungkinkan untuk konfigurasi wireless yang sedikit berbeda untuk meningkatkan jangkauan area jaringan wireless dengan menggunakan beberapa perangkat Acess Point menjadi sebuah kesatuan (Tulloh, Hariyani, Hafidh, \& Pertiwi, 2017). Topologi jaringan di Universitas Muhammadiyah jember dapat memberikan solusi atas keluhan-keluhan mahasiswa dan dosen dengan menggunakan topologi WDS Mesh (Cahyanto, 2018). Topologi jaringan yang ada di Universitas Muhammadiyah Jember memiliki beberapa gedung yang setiap gedung dan lantainya terdapat sebuah Access Point yang di letakkan secara horisontal dan vertikal yang berfungsi mencakup seluruh area hotspot (Cahyanto, Oktavianto, \& Royan, 2013). Topologi tersebut menyerupai sebuah jala atau jaring, oleh karena itu, untuk mengatasi masalah tersebut digunakanlah WDS Mesh.

\section{TINJAUAN PUSTAKA}

\subsection{Topologi Mesh}

Topologi mesh merupakan sebuah bentuk topologi jaringan dimana setiap node terhubung langsung dengan node lain pada jaringan hingga membentuk rangkaian menyerupai jala/jaring (Silo, 2013). Setiap node terhubung secara langsung dengan node yang lain maka ketika akan berkomunikasi setiap node tidak memerlukan perantara atau biasa disebut dedicated links. Berdasarkan pemaparan diatas kita bisa mengambil beberapa perhitungan dalam topologi mesh. Misalnya terdapat 6 komputer dalam jaringan maka kabel koneksi yang diperlukan agar jaringan bekerja maksimal adalah $6(6-1) / 2=15$. Koneksi dengan rumus $n$ (n-1) / 2 dan masing-masing komputer diharuskan memiliki Port I/O sejumlah 6-1= 5 Port I/O dengan rumus $n-1$.

\subsection{Jaringan Nirkabel}

Wireless merupakan jaringan tanpa kabel yang menggunakan udara sebagai media transmisinya untuk menghantarkan gelombang elektromagnetik (Sulistiyawati, Syafei, \& Santoso, 2015). Perkembangan wireless sebenarnya telah dimulai sejak lama dan telah dibuktikan secara ilmiah oleh para ilmuan dengan penemuan radio dan kemudian dilanjutkan dengan penemuan radar. Kemudian dengan perkembangan kebutuhan informasi bagi manusia, maka penggunaan wireless semakin banyak dan tidak hanya untuk penggunaan radio dan radar saja. Saat ini teknologi wireless berkembang pesat, secara kasat mata dapat dilihat dengan semakin banyaknya pemakaian telepon seluler, selain itu berkembang pula teknologi wireless yang di gunakan untuk akses internet (Cahyanto, 2011). Wireless LAN adalah suatu jaringan komputer yang saling terhubung melalui tanpa kabel. Local Area Network dari komputer maupun dari peralatan lainnya dapat dikembangkan lewat sinyal radio . Teknologi Wireless LAN ada yang menggunakan frekuensi radio untuk mengirim dan menerima data tanpa membutuhan kabel untuk saling menghubungkan. Akibatnya pengguna mempunyai fleksibilitas yang tinggi dan tidak tergantung pada suatu tempat atau lokasi. Era globalisasi sekarang ini sudah banyak tempat-tempat yang menyediakan koneksi LAN dengan 
teknologi Wifi yang biasa disebut dengan hotspot. Hal ini memungkinkan seseorang dengan komputer dengan kartu nirkabel (wireless card) atau personal digital assistant (PDA) untuk terhubung dengan internet dengan menggunakan titik akses (hotspot) terdekat.

\subsection{Wireless Distribution System}

Pengertian Wireless Distribution Sistem (WDS) adalah sebuah perangkat (AP) access point (menggunkan modebridge / ap-bridge) memungkinkan untuk membangun sebuah jaringan Wireless Distribution Sistem dengan perangkat AP lain (Muhammad, Indah, \& Andriana, 2017). Penggunaan WDS memungkinkan jaringan wireless dikembangkan menggunakan beberapa access point tanpa harus memerlukan backbone kabel jaringan untuk menghubungkan beberapa access point yang ada. Wireless Distribution System (WDS) juga didefinisikan sebagai mode repeater jalur penghubung karena dapat sebagai bridge dan juga menerima wireless client pada saat bersamaan. Tetapi perlu diperhatikan bahwa throughtput dalam mode ini menjadi setengahnya untuk semua client yang terhubung secara wireless. Adapun syaratsyarat untuk membangun Wireless Distribution System (WDS) adalah :

a. Access Point utama maupun Access Point Repeater harus mendukung WDS.

b. Masing-masing IP Address Acces Point tidak boleh sama.

c. Channel radio yang di gunakan harus sama.

d. Matikan layanan DHCP server pada Access Point Repeater, karena DHCP akan di ambil alih Access Point utama sebagai default gateway.

e. Sebagaian besar authentication Accees Point yang didukung dalam WDS adalah WEP 64/128 bit. Semua Access Point yang terlibat dalam 1 koneksi harus menggunakan metode enkripsi/authentication yang sama.

\subsection{WDS Mesh}

Jaringan wireless mesh adalah sebuah jaringan wireless point to point dan multi point to point, namun pada jaringan wireless mesh setiap perangkat mesh memiliki fungsi point to point dan multi point to point pada saat bersamaan. Pada jaringan wireless biasa dikenal dengan istilah repeater dan WDS (Sukadarmika, Er, \& Saputra, 2010). Jaringan wireless mesh sebenarnya menganut system yang sama tapi lebih dikembangkan lagi ke jaringan routing sehingga setiap perangkat mesh bisa dipantau dengan mudah, diatur dengan remote dan dalam instalasi yang wirelessly.

\section{METODE PENELITIAN}

\subsection{Pengumpulan Data}

Wawancara merupakan pengkajian terhadap masalah yang diambil dengan cara mewawancarai pihak yang telah mengetahui struktur jaringan bagaimana penyelesaian masalah yang diinginkan. Dalam wawancara ini dilakukan kepada staff UPT Pusat Data dan Informasi sebagai unit yang menangani masalah TI yang juga termasuk jaringan internet yang ada di Universitas Muhammadiyah Jember sehingga disimpulkan bahwa Universitas Muhammadiyah ingin menerapkan penggunaan metode WDS (wireless distribution system) diharapkan dapat meningkatkan pelayanan internet yang ada pada Universitas Muhammadiyah Jember.

\subsection{Study Literatur}

Pendalaman materi di dapatkan dengan cara pencarian informasi melalui internet dan buku yang berkaitan dengan wireless distribution system, ada beberapa mode operasional yang paling penting terdiri dari:

a. Dynamic

Dynamic WDS interface adalah apabila proses pembentukan hubungan antara AP satu dengan AP lainnya dilakukan secara dynamic/secara otomatis akan segera dibuat.

b. Static

Static WDS interface adalah apabila proses pembentukan hubungan antara AP satu dengan AP yang lainnya harus dilakukan secara manual, dengan memasukkan MAC address AP yang lainnya.

c. Dynamic mesh

Dynamic mesh interface adalah hampir sama dengan mode dynamic tetapi menggunakan protokol HWMP+ (penyempurnaan WDS standar)

d. Static mesh

Static mesh interface adalah cara kerja dan kegunaannya hampir sama dengan mode static, tetapi sudah menggunakan protokol baru sebagai penyempurnaan WDS standar yaitu protokol HWMP+ (penyempurnaan WDS standar.

\subsection{Perancangan}

Perancangan pada wireless mana saja yang akan di buat menjadi Wireless Distribution System Mesh di Universitas Muhammadiyah Jember.

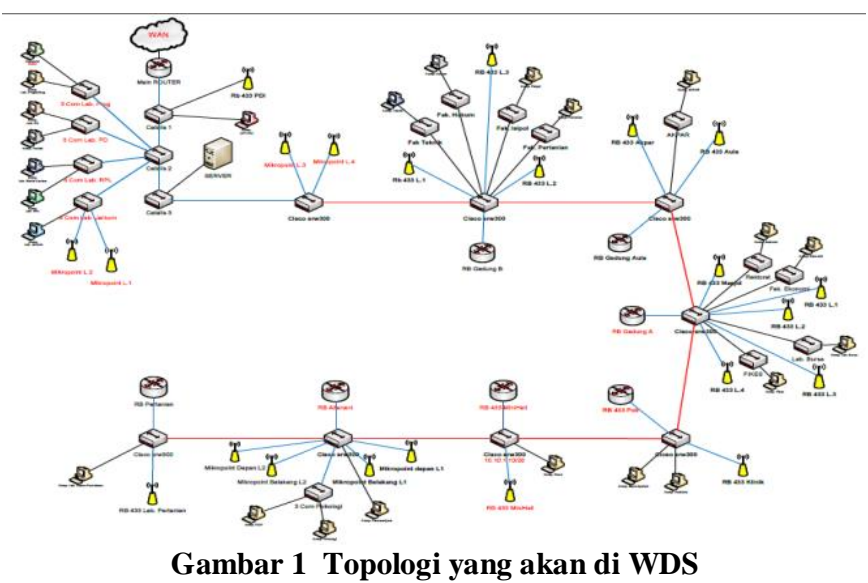

Gambar tersebut menjelaskan beberapa keterangan tentang jaringan yang akan di WDS pada Universitas Muhammadiyah Jember. Implementasi ini berfokus pada cara yang akan di setting pada setiap Access Point/Wireless yang akan di optimalkan menjadi Wireless Distribution System sehingga nantinya meningkatkan area jangkauan dan koneksi.

\subsection{Analisis}

Analisis yang digunakan dalam implementasi WDS adalah dengan merancang skema jaringan serta membandingkan sebuah Wireless Distribution System Mesh. WDS adalah sistem yang memungkinkan interkoneksi nirkabel jalur akses dalam jaringan IEEE 802.11. Hal ini memungkinkan jaringan nirkabel untuk diperluas menggunakan beberapa jalur akses tanpa persyaratan tradisional untuk backbone kabel. Penggunaan WDS system memungkinkan untuk melakukan konfigurasi Wireless yang sedikit berbeda untuk meningkatkan jangkauan area jaringan wireless menggunakan beberapa perangkat AP menjadi sebuah satu kesatuan. Penggunaan WDS ini memungkinkan komunikasi data melewati beberapa AP seperti halnya sebuah jaringan ethernet, diibaratkan AP tersebut sebagai sebuah switch. 


\subsection{Mekanisme Pengujian}

Pengujian dilakukan pada minilab yang dibangun dengan menggunakan 3 Router Mikrotik RouterBoard 951-2nd yang saling terhubung membentuk topologi Mesh. Pengujian dilakukan berkala dengan menghubungkan setiap AP pada jarak 1 meter, 3 meter, 5 meter dan 8 meter secara berpindahpindah dengan parameter yang digunakan sebagai indikator pengujian adalah Signal Strength, Troughtput, $C C Q$ dan Signal to Noise yang bertujuan untuk melihat kualitas jaringan jika menggunakan Wireless Distribution System dengan topologi Mesh.

\section{HASIL DAN PEMBAHASAN}

\subsection{Konfigurasi Router Utama WDS}

Setting Wireless dengan konfigurasi AP Bridge dengan SSID WDS 1.

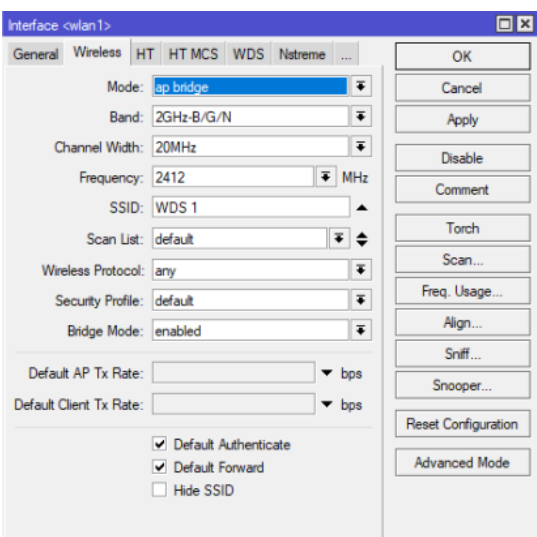

Gambar 2 Interface Wireless

Di menu WDS Wireless mode WDS dynamic Mesh dan pilih WDS Default Bridge dengan Mesh yang sudah bangun.

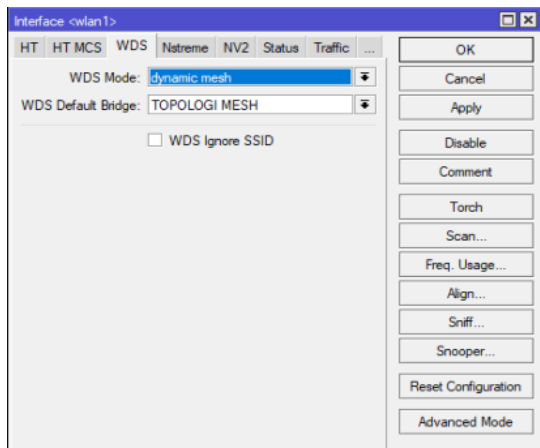

Gambar 3 Setting Wireless WDS

Pengalamatan pada router yang akan digunakan untuk WDS Mesh dengan menggunakan alamat 192.168.1.1/24 dengan interface Mesh yang sudah di bangun di awal.

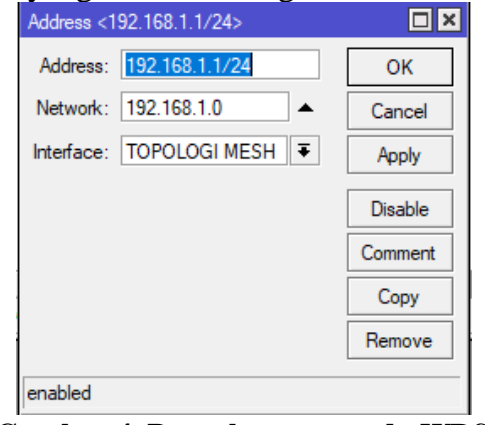

Gambar 4 Pengalamatan pada WDS
Konfigurasi routing pada WDS dengan menggunakan routing MME dengan interface Mesh yang sudah dibangun.

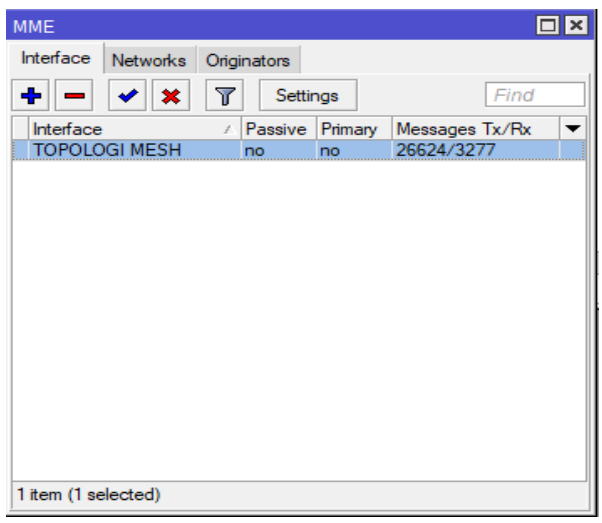

Gambar 5 Routing MME

\subsection{Konfigurasi Client WDS Mesh}

Bangun Mesh terlebih dahulu sesuai dengan gambar 2 . Setting Wireless WDS sesuai dengan gambar 4 dan bangun routing agar bisa saling terhubung antara router utama dengan router client dengan routing $M M E$ sesuai dengan gambar 5 diatas. Konfigurasi Wireless Client dengan mode WDS Slave.

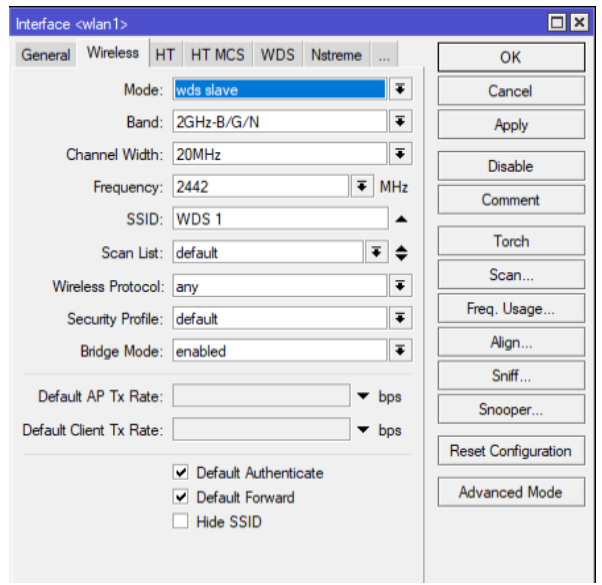

Gambar 6 Konfigurasi WDS Client

Pengalamatan WDS Client menggunakan DHCP Client dengan interface Mesh yang sudah dibangun.

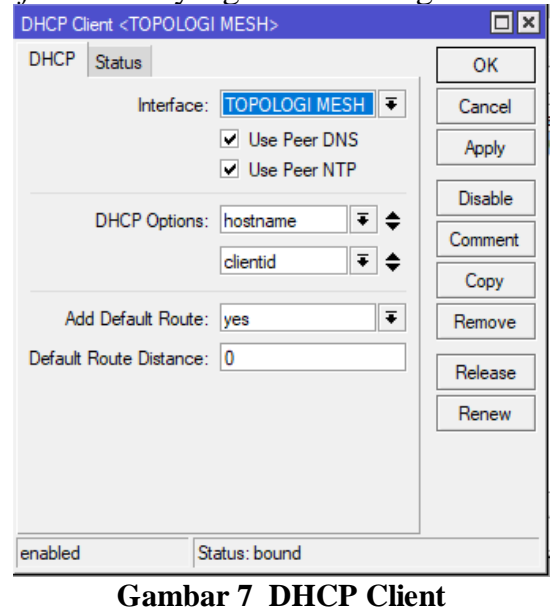

\subsection{Proses Pengujian}

Proses pengujian dimaksud untuk mengetahui kinerja WDS Mesh dengan indikator pengujian diantaranya adalah $C C Q$, Signal Noise, Throughput, Signal Strength pada Access Point yang ada di Universitas Muhamadiyah Jember sebagai uji untuk menentukan hasil WDS Mesh. 


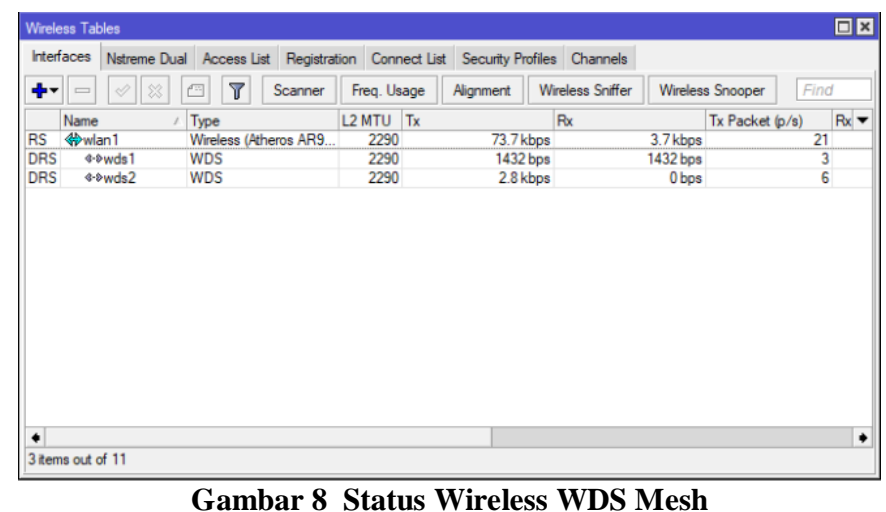

Gambar 8 Status Wireless WDS Mesh

Gambar 8 menunjukan Konfigurasi WDS Mesh berhasil dengan indikator name $w d s 1$ dan $w d s 2$ serta statusnya DRSA = Dynamic Running Slave Active.

Wireless pada AP utama

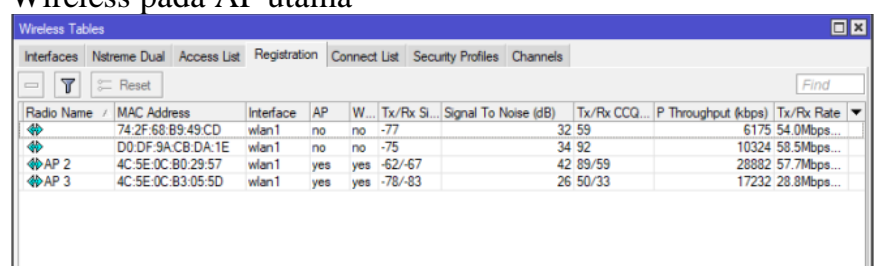

Gambar 9 Registration Wireless pada AP utama

Wireless pada AP 2

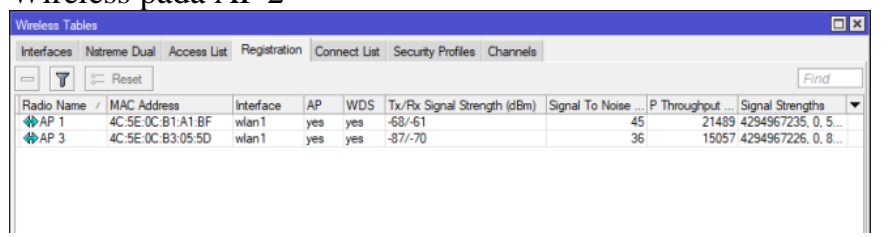

Gambar 10 Registration Wireless pada AP 2

Wireless pada AP 3

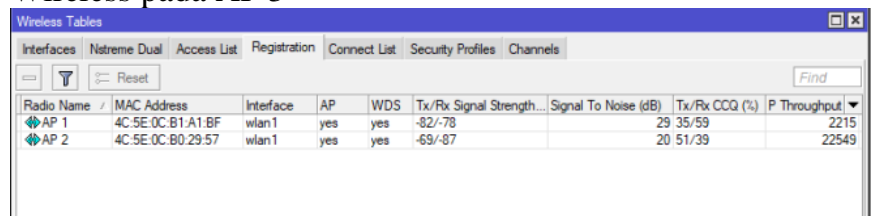

Gambar 11 Registration Wireless pada AP 3

Gambar diatas adalah untuk menguji dan melihat nilai dari Signal to Noise, CCQ, Signal Strength, dan Throughput yang akan diuji.

\subsection{Perhitungan dan Analisa Data}

Penrhitungan jarak antar access point dilakukan untuk melihat TX/RX dari access point sebagai bahan untuk membandingkan hasil perhitungan, apakah sesuai dengan standar yang ada, dan berikut adalah hasil uji $T X / R X$ pada beberapa AP:

\section{Tabel 1 Contoh Pengujian antar AP}

\begin{tabular}{|c|c|c|}
\hline \multicolumn{3}{|l|}{ Jarak Antar AP } \\
\hline NAMA AP & $\mathrm{Tx}$ & $\mathrm{Rx}$ \\
\hline AP 1.4 dengan 1.5 & -78 & -70 \\
\hline AP 1.4 dengan 2.4 & -74 & -68 \\
\hline AP 1.4 dengan 2.5 & -86 & -92 \\
\hline
\end{tabular}

Dari tabel diatas, koneksi antar AP kurang baik karena nilai rata-rata TX/RX diatas -70 karena jika minusnya semakin jauh dari angka 0 maka akan semakin kuat sinyalnya. Oleh karena itu, jika mode WDS antar AP akan saling terkoneksi, client tidak perlu mengkoneksikan kembali karena device dari client akan berpindah secara otomatis dikarenakan semua AP saling terkoneksi

\subsection{Pengujian Device Terhadap WDS MESH}

Pengujian menggunakan device ini bertujuan untuk mengetahui nilai dari CCQ, Signal Noise, Throughput, Signal Strength pada access point dengan jarak pengujian 1 Meter, 3 Meter, 5 Meter dan 8 Meter dari AP, dan berikut adalah tabel hasil dari pengujian device terhadap WDS Mesh.

Tabel 2 Pengujian Signal Strengths Device terhadap AP

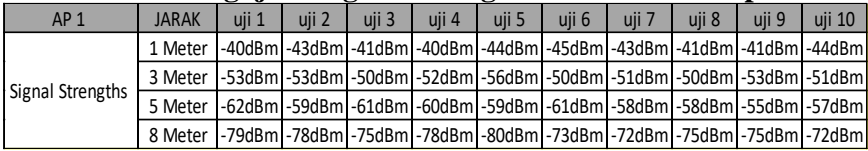

Dari 10 kali uji yang dilakukan dengan jarak 1,3,5 dan 8 meter menunjukan hasil yang baik dengan rata rata nilai Signal Strength -68 dBm dan baik untuk untuk koneksi antara device dengan AP yang sudah di mode WDS.

Tabel 3 Pengujian CCQ Device terhadap AP

\begin{tabular}{|c|c|c|c|c|c|c|c|c|c|c|c|}
\hline AP1 & JARAK & Uji 1 & Uji 2 & Uji 3 & Uji 4 & Uji 5 & Uji 6 & Uji 7 & Uji 8 & Uji 9 & Uji 10 \\
\hline \multirow{4}{*}{ CCQ } & 1 meter & $100 \%$ & $100 \%$ & $99 \%$ & $98 \%$ & $100 \%$ & $99 \%$ & $97 \%$ & $96 \%$ & $98 \%$ & $99 \%$ \\
\cline { 2 - 11 } & 3 meter & $98 \%$ & $98 \%$ & $94 \%$ & $93 \%$ & $95 \%$ & $94 \%$ & $99 \%$ & $93 \%$ & $94 \%$ & $91 \%$ \\
\cline { 2 - 10 } & 5 meter & $95 \%$ & $90 \%$ & $90 \%$ & $90 \%$ & $89 \%$ & $87 \%$ & $91 \%$ & $99 \%$ & $89 \%$ & $95 \%$ \\
\cline { 2 - 10 } & 8 meter & $85 \%$ & $80 \%$ & $87 \%$ & $84 \%$ & $82 \%$ & $80 \%$ & $87 \%$ & $85 \%$ & $86 \%$ & $87 \%$ \\
\hline
\end{tabular}

Dari 10 kali uji yang dilakukan dengan jarak 1,3,5 dan 8 meter menunjukkan hasil yang baik dengan rata-rata nilai CCQ $84 \%$ dBm dan baik untuk untuk koneksi antara device dengan AP yang sudah di mode WDS.

Tabel 4 Pengujian Signal Noise Device terhadap AP \begin{tabular}{|c|c|c|c|c|c|c|c|c|c|c|c|}
\hline AP1 & JARAK & Uji 1 & Uji 2 & Uji 3 & Uji 4 & Uji 5 & Uji 6 & Uji 7 & Uji 8 & Uji 9 & Uji 10 \\
\hline \multirow{4}{*}{ Signal Noise } & 1 meter & $60 \mathrm{~dB}$ & $61 \mathrm{~dB}$ & $63 \mathrm{~dB}$ & $59 \mathrm{~dB}$ & $61 \mathrm{~dB}$ & $59 \mathrm{~dB}$ & $54 \mathrm{~dB}$ & $62 \mathrm{~dB}$ & $59 \mathrm{~dB}$ & $65 \mathrm{~dB}$ \\
\cline { 2 - 11 } & 3 meter & $51 \mathrm{~dB}$ & $55 \mathrm{~dB}$ & $44 \mathrm{~dB}$ & $49 \mathrm{~dB}$ & $55 \mathrm{~dB}$ & $54 \mathrm{~dB}$ & $60 \mathrm{~dB}$ & $57 \mathrm{~dB}$ & $52 \mathrm{~dB}$ & $53 \mathrm{~dB}$ \\
\cline { 2 - 11 } & 5 meter & $40 \mathrm{~dB}$ & $43 \mathrm{~dB}$ & $43 \mathrm{~dB}$ & $47 \mathrm{~dB}$ & $43 \mathrm{~dB}$ & $47 \mathrm{~dB}$ & $46 \mathrm{~dB}$ & $60 \mathrm{~dB}$ & $47 \mathrm{~dB}$ & $50 \mathrm{~dB}$ \\
\cline { 2 - 11 } & 8 meter & $59 \mathrm{~dB}$ & $41 \mathrm{~dB}$ & $34 \mathrm{~dB}$ & $41 \mathrm{~dB}$ & $41 \mathrm{~dB}$ & $44 \mathrm{~dB}$ & $39 \mathrm{~dB}$ & $52 \mathrm{~dB}$ & $45 \mathrm{~dB}$ & $47 \mathrm{~dB}$ \\
\hline
\end{tabular}

Dari 10 kali uji yang dilakukan dengan jarak 1,3,5 dan 8 meter menunjukan hasil yang baik dengan rata-rata nilai Signal Noise $49 \mathrm{~dB}$ dan baik untuk untuk koneksi antara device dengan AP yang sudah di mode WDS.

Tabel 5 Pengujian Throughput Device terhadap AP

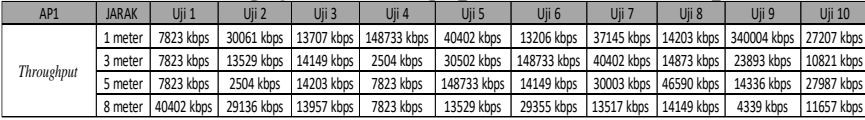

Dari 10 kali uji yang dilakukan dengan jarak 1,3,5 dan 8 meter menunjukan hasil yang baik dengan rata-rata nilai Throughput 31,136 kbps dan baik untuk koneksi antara device dengan AP yang sudah di mode WDS.

\subsection{Rata-Rata Hasil Pengujian}

Hitung hasil rata-rata hasil pengujian dari setiap hasil uji $C C Q$, Signal Noise, Throughput, Signal Strengths pada access point dengan jarak pengujian 1 Meter, 3 Meter, 5 Meter dan 8 Meter dari AP 1, AP 2 dan AP3 dengan rumus sebagai berikut.

A : Jumlah Uji

B : Jumlah Total dari semua uji

$$
\frac{B}{A} X 100 \%=\%
$$


Contoh Perhitungan :

- $\quad$ Rata-rata CCQ

A : Jumlah Uji

B : Jumlah Total dari semua uji

jadi, $\frac{B}{A} X 100=\frac{986}{10} X 100=99 \%$

- Rata-rata Signal Noise

A : Jumlah Uji

B : Jumlah Total dari semua uji

jadi, $\frac{B}{A} X 100=\frac{603}{10} X 100=60 d B$

- Rata-rata Throughput

A : Jumlah Uji

B : Jumlah Total dari semua uji

jadi, $\frac{B}{A} X 100=\frac{672.491}{10} X 100=67,249 \mathrm{kbps}$

- Rata-rata Signal Strengths

A : Jumlah Uji

B : Jumlah Total dari semua uji jadi, $\frac{B}{A} X 100=\frac{-422}{10} X 100=-42,2 \mathrm{dBm}$

Hasil perhitungan rata-rata diatas adalah $C C Q$, Signal Noise, Throughput, Signal Strengths pada access point dengan jarak pengujian 1 Meter, 3 Meter, 5 Meter dan 8 Meter dari AP 1, AP 2 dan AP3 pada tabel berikut.

Tabel 6 Rata-rata CCQ, Signal Noise, Throughput, Signal Strengths AP 1

\begin{tabular}{|c|c|c|c|c|l|}
\hline \multirow{4}{*}{ AP 1 } & Jarak & CCQ & $\begin{array}{c}\text { Signal } \\
\text { Noise }\end{array}$ & Throughput & Signal Strengths \\
\cline { 2 - 6 } & 1 Meter & $99 \%$ & $60 \mathrm{~dB}$ & $67.249 \mathrm{kbps}$ & $-42,2 \mathrm{dBm}$ \\
\cline { 2 - 6 } & 3 Meter & $95 \%$ & $53 \mathrm{~dB}$ & $30.723 \mathrm{kbps}$ & $-51,9 \mathrm{dBm}$ \\
\cline { 2 - 6 } & $5 \mathrm{Meter}$ & $92 \%$ & $47 \mathrm{~dB}$ & $31.415 \mathrm{kbps}$ & $-59 \mathrm{dBm}$ \\
\cline { 2 - 6 } & $8 \mathrm{M}$ Meter & $84 \%$ & $44 \mathrm{~dB}$ & $17.786 \mathrm{kbps}$ & $-75,7 \mathrm{dBm}$ \\
\hline
\end{tabular}

Tabel 7 Rata-rata CCQ, Signal Noise, Throughput, Signal Strengths AP 2

\begin{tabular}{|c|c|c|c|c|l|}
\hline \multirow{4}{*}{ AP 2 } & Jarak & CCQ & $\begin{array}{l}\text { Signal } \\
\text { Noise }\end{array}$ & Throughput & Signal Strengths \\
\cline { 2 - 6 } & 1 Meter & $98 \%$ & $58 \mathrm{~dB}$ & $70.112 \mathrm{kbps}$ & $-42,4 \mathrm{dBm}$ \\
\cline { 2 - 6 } & 3 Meter & $94 \%$ & $55 \mathrm{~dB}$ & $30.372 \mathrm{kbps}$ & $-53,8 \mathrm{dBm}$ \\
\cline { 2 - 6 } & 5 Meter & $91 \%$ & $51 \mathrm{~dB}$ & $31.136 \mathrm{kbps}$ & $-56 \mathrm{dBm}$ \\
\cline { 2 - 6 } & 8 Meter & $87 \%$ & $47 \mathrm{~dB}$ & $15.930 \mathrm{kbps}$ & $-74,5 \mathrm{dBm}$ \\
\hline
\end{tabular}

Tabel 8 Rata-rata CCQ, Signal Noise, Throughput, Signal Strengths AP 3

\begin{tabular}{|l|c|c|c|c|l|}
\hline & Jarak & CCQ & $\begin{array}{l}\text { Signal } \\
\text { Noise }\end{array}$ & Throughput & Signal Strengths \\
\cline { 2 - 6 } AP 3 & 1 Meter & $99 \%$ & $58 \mathrm{~dB}$ & $37.813 \mathrm{kbps}$ & $-42,9 \mathrm{dBm}$ \\
\cline { 2 - 6 } & 3 Meter & $95 \%$ & $53 \mathrm{~dB}$ & $25.790 \mathrm{kbps}$ & $-50,5 \mathrm{dBm}$ \\
\cline { 2 - 6 } & 5 Meter & $92 \%$ & $49 \mathrm{~dB}$ & $18.943 \mathrm{kbps}$ & $-57,6 \mathrm{dBm}$ \\
\cline { 2 - 6 } & 8 Meter & $88 \%$ & $48 \mathrm{~dB}$ & $17.484 \mathrm{kbps}$ & $-76 \mathrm{dBm}$ \\
\hline
\end{tabular}

\subsection{Grafik perhitungan}

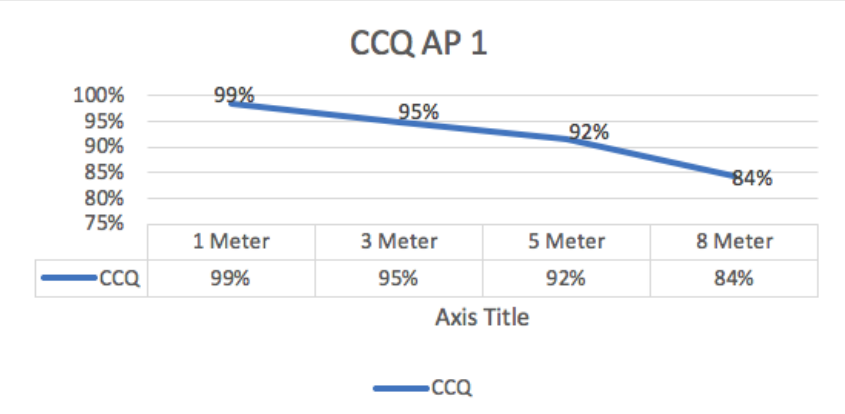

Gambar 12 Grafik CCQ AP 1
Dari hasil ujicoba yang dilakukan dapat dilihat pada grafik diatas nilai CCQ device terhadap AP 1. Jarak 1 meter 99\%, jarak 3 meter $95 \%$, jarak 5 meter $92 \%$ dan jarak 8 meter $84 \%$.

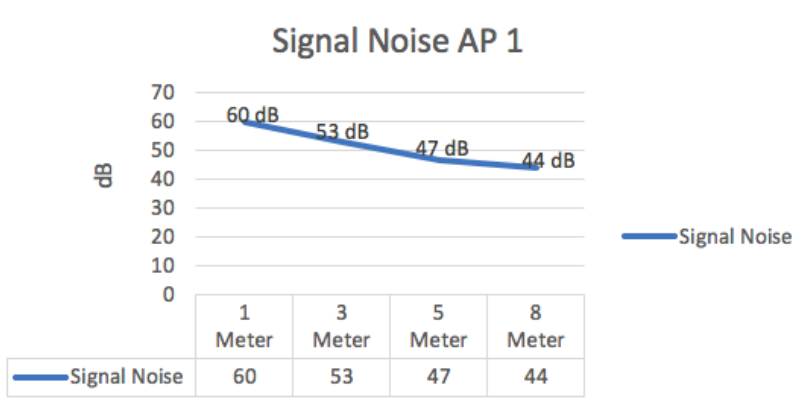

Gambar 13 Grafik Signal Noise AP 1

Dari hasil ujicoba yang dilakukan dapat dilihat pada grafik diatas nilai Signal Noise device terhadap AP 1. Jarak 1 meter $60 \mathrm{~dB}$, jarak 3 meter $53 \mathrm{~dB}$, jarak 5 meter $47 \mathrm{~dB}$ dan jarak 8 meter $44 \mathrm{~dB}$.

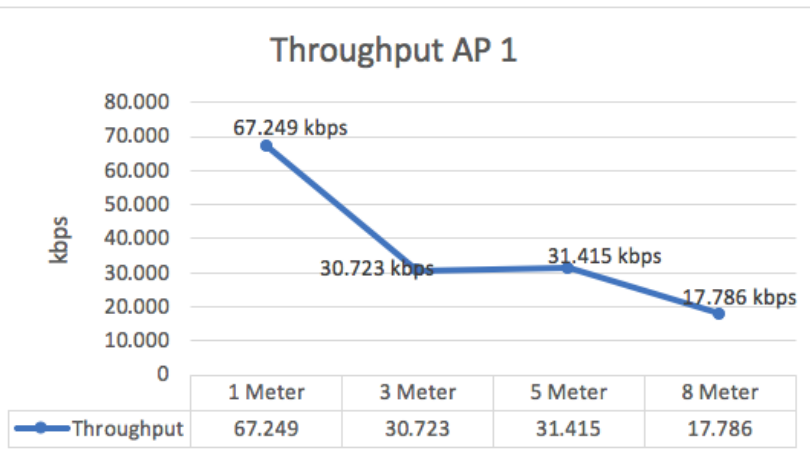

Gambar 14 Grafik Throughput AP 1

Dari hasil ujicoba yang dilakukan dapat dilihat pada grafik diatas nilai Signal Noise device terhadap AP 1. Jarak 1 meter $67.249 \mathrm{kbps}$, jarak 3 meter $30.723 \mathrm{kbps}$, jarak 5 meter 31.415 kbps dan jarak 8 meter 17.786 kbps.

\section{Signal Strengths AP 1}

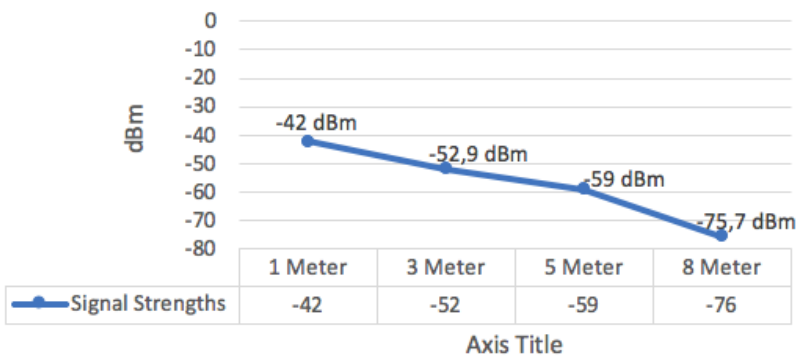

Gambar 15 Grafik Signal Strenghts AP 1

Dari hasil ujicoba yang dilakukan dapat dilihat pada grafik diatas nilai Signal Noise device terhadap AP 1. Jarak 1 meter $42 \mathrm{dBm}$, jarak 3 meter $-52,9 \mathrm{dBm}$, jarak 5 meter $-59 \mathrm{dBm}$ dan jarak 8 meter $-75,7 \mathrm{dBm}$. 


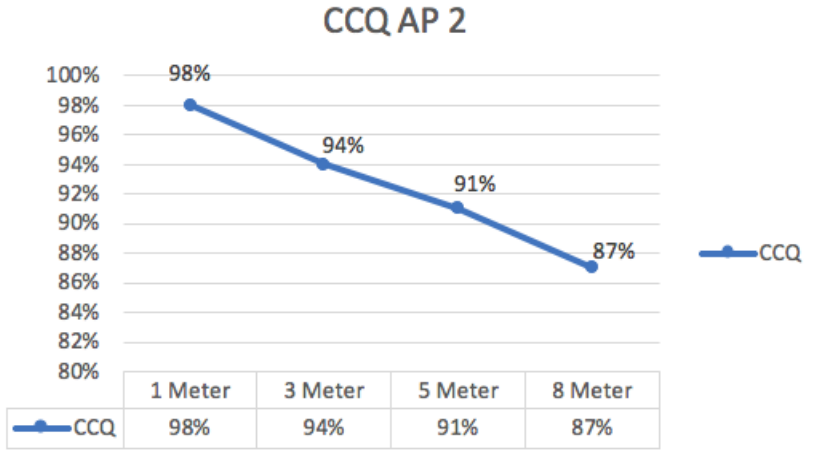

Gambar 16 Grafik CCQ AP 2

Dari hasil ujicoba yang dilakukan dapat dilihat pada grafik diatas nilai CCQ device terhadap AP 2. Jarak 1 meter $98 \%$, jarak 3 meter $94 \%$, jarak 5 meter $91 \%$ dan jarak 8 meter $87 \%$.

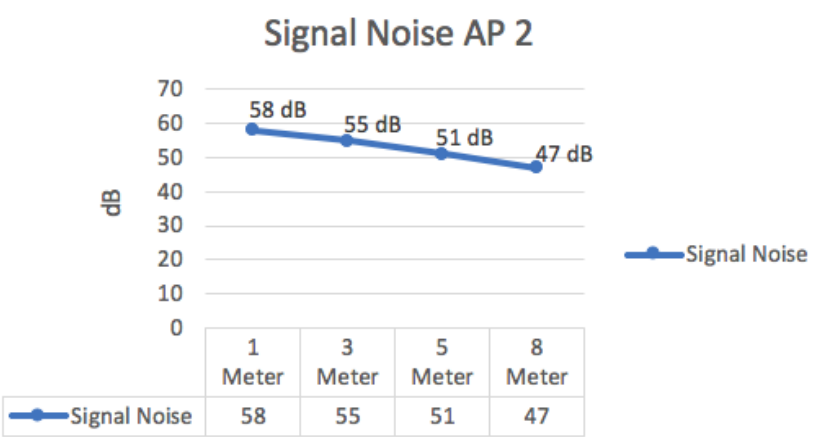

Gambar 17 Grafik Signal Noise AP 2

Dari hasil ujicoba yang dilakukan dapat dilihat pada grafik diatas nilai Signal Noise device terhadap AP 1. Jarak 1 meter $58 \mathrm{~dB}$, jarak 3 meter $55 \mathrm{~dB}$, jarak 5 meter $51 \mathrm{~dB}$ dan jarak 8 meter $47 \mathrm{~dB}$.

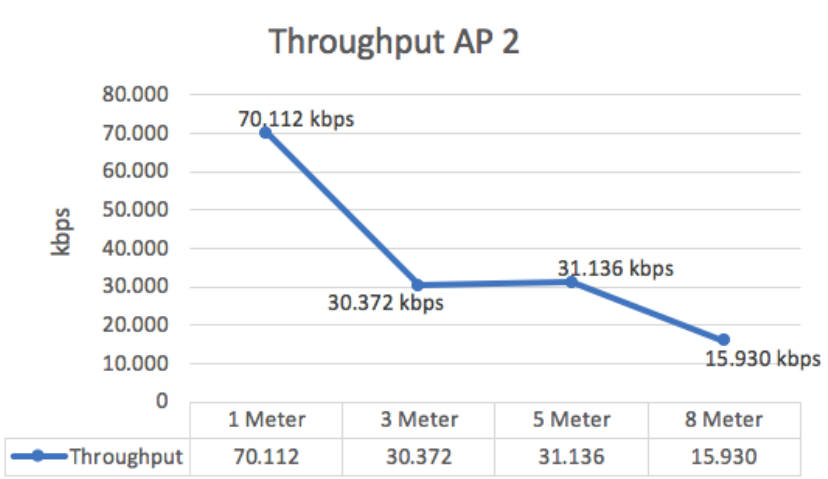

Gambar 18 Grafik Throughput AP 2

Dari hasil ujicoba yang dilakukan dapat dilihat pada grafik diatas nilai Signal Noise device terhadap AP 1. Jarak 1 meter $70.122 \mathrm{kbps}$, jarak 3 meter $30.372 \mathrm{kbps}$, jarak 5 meter 31.136 kbps dan jarak 8 meter 15.930 kbps.
Signal Strengths AP 2

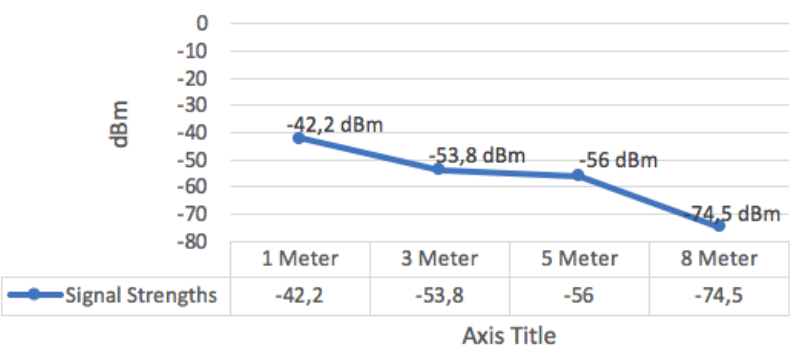

Gambar 19 Grafik Signal Strengths AP 2

Dari hasil ujicoba yang dilakukan dapat dilihat pada grafik diatas nilai Signal Noise device terhadap AP 1. Jarak 1 meter 42,2 dBm, jarak 3 meter $-53,8 \mathrm{dBm}$, jarak 5 meter $-56 \mathrm{dBm}$ dan jarak 8 meter $-74,5 \mathrm{dBm}$.

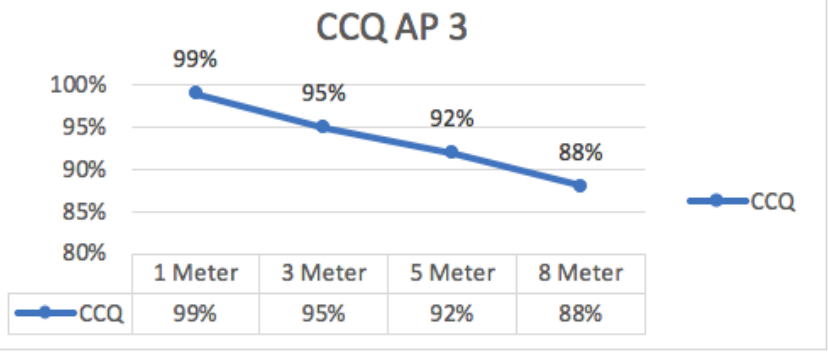

Gambar 20 Grafik CCQ AP 3

Dari hasil ujicoba yang dilakukan dapat dilihat pada grafik diatas nilai $C C Q$ device terhadap AP 2. Jarak 1 meter 99\%, jarak 3 meter $95 \%$, jarak 5 meter $92 \%$ dan jarak 8 meter $88 \%$.

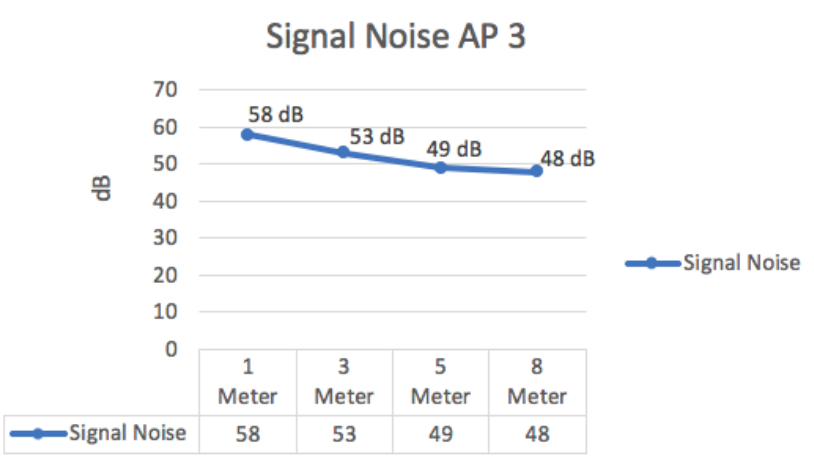

Gambar 21 Grafik Signal Noise AP 3

Dari hasil ujicoba yang dilakukan dapat dilihat pada grafik diatas nilai Signal Noise device terhadap AP 1. Jarak 1 meter $58 \mathrm{~dB}$, jarak 3 meter $53 \mathrm{~dB}$, jarak 5 meter $49 \mathrm{~dB}$ dan jarak 8 meter $48 \mathrm{~dB}$.

\section{Throughput AP 3}

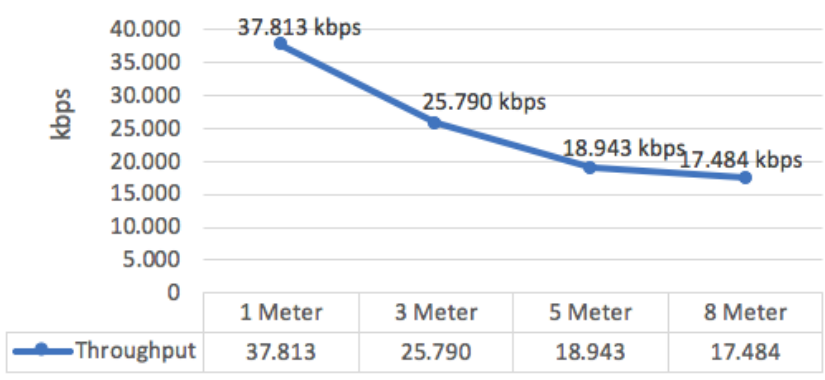

Gambar 22 Grafik Throughput AP 3

Dari hasil ujicoba yang dilakukan dapat dilihat pada grafik diatas nilai Signal Noise device terhadap AP 1. Jarak 1 meter 
37.813 kbps, jarak 3 meter 25.790 kbps, jarak 5 meter 18.943 kbps dan jarak 8 meter 17.484 kbps.

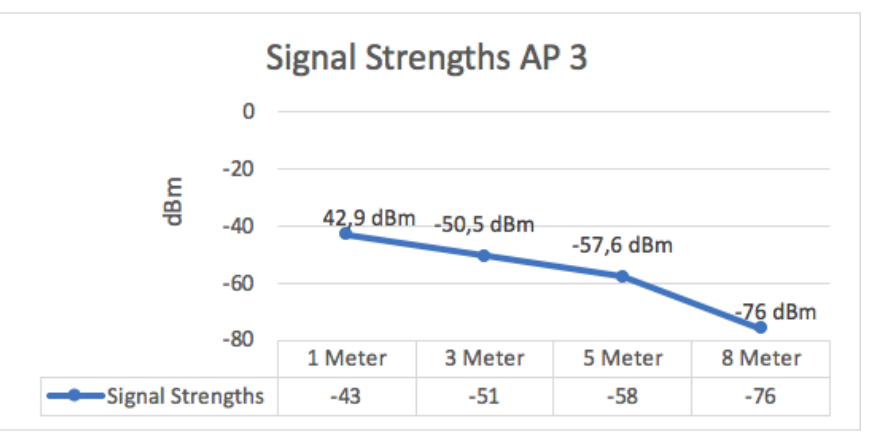

Gambar 23 Grafik Signal Strengths AP 3

Dari hasil ujicoba yang dilakukan dapat dilihat pada grafik diatas nilai Signal Noise device terhadap AP 1. Jarak 1 meter 42,9 dBm, jarak 3 meter $-50,5 \mathrm{dBm}$, jarak 5 meter $-57,6 \mathrm{dBm}$ dan jarak 8 meter $-76 \mathrm{dBm}$.

\section{KESIMPULAN DAN SARAN}

5.1 Kesimpulan

Hasil uji dan analisa yang dilakukan pada bab IV dapat disimpulkan sebagai berikut:

1. WDS Mesh mampu meng-coverage area wifi di Universitas Muhammadiyah Jember.

2. Penggunaan WDS Mesh jauh lebih baik karena semua AP saling terkoneksi dibandingkan dengan WDS yang biasa yang hanya di setting per lantai saja untuk koneksi WDS antar AP.

3. WDS Mesh semua AP yang ada di lantai 1 atau 2 di gedung Universitas muhamadiyah saling terkoneksi di setiap gedung itu sendiri.

4. Sesuai hasil pengujian dan analisa device client terhadap AP yang sudah di WDS Mesh dengan parameter Signal Strenghs, CCQ, Signal to Noise, Throughput dapat dikategorikan Excellent (Bagus).

5. Kelebihan dari WDS Mesh dalam koneksi indoor dalam radius 5 sampai 10 meter jauh lebih baik daripada WDS biasa dengan Throughput yang dihasilkan oleh WDS Mesh adalah 31,136 kbps sedangkan WDS biasanya hanya menghasilkan Throughput 23,597 kbps

\subsection{Saran}

Beberapa saran yang dapat dijadikan pertimbangan dalam mengembangkan penelitian ini adalah :

1. Pengembang bisa melakukan analisa dengan parameter yang lain selain yang ada didalam penelitian ini misal analisa pada $Q o S$ WDS, dengan tujuan mengembangkan WDS Mesh.

2. Membangun WDS dengan topologi yang lain di Universitas Muhammadiyah Jember.

\section{DAFTAR PUSTAKA}

Cahyanto, T. A. (2011). Analisis deteksi penyusupan pada jaringan komputer menggunakan snort (studi kasus pada Dinas Pariwisata Propinsi Daerah Istimewa Yogyakarta). Yogyakarta. Retrieved from http://search.jogjalib.com/Record/uinsukalib073461\#details

Cahyanto, T. A. (2018). Penerapan Teknologi Web Service
Pada Sistem Informasi Data Rekam Medis Rumah Sakit XYZ. Query: Jurnal Sistem Informasi, 5341(April), 2532.

Cahyanto, T. A., Oktavianto, H., \& Royan, A. W. (2013). Analisis dan Implementasi Honeypot Menggunakan Dionaea Sebagai Penunjang Keamanan Jaringan. JUSTINDO (Jurnal Sistem Dan Teknologi Informasi Indonesia), 1(2), 86-92.

Markhadam, A. (2016). Perancangan dan Analisa Pemanfaatan Access Point Menggunakan Wireless Distribution Sistem.

Muhammad, D., Indah, G., \& Andriana, G. (2017). An Experimental Connectivity Performance of Simple Wireless Mesh Implementation Using Wireless Distribution System (WDS). International Journal of Applied Information Technology, 01(02), 0-3.

Putra, D. L. A., \& KH, A. S. (2011). ANALISA KINERJA IMPLEMENTASI WIRELESS DISTRIBUTION SYSTEM PADA PERANGKAT ACCESS POINT 802.11 G MENGGUNAKAN OPENWRT, 1-6.

Silo, W. T. (2013). Analisis Quality of Service pada Transfer Data Audio dan Video Melalui WDS ( Wireless Distribution System ), (November).

Sukadarmika, G., Er, N. I., \& Saputra, N. W. (2010). Analisis Coverage WLAN (Wireless Local Area Network) 802 . 11a Menggunakan OPNET Modeler. Teknologi Elektro, 9(2), 143-151.

Sulistiyawati, R. I., Syafei, W. A., \& Santoso, I. (2015). Rancang Bangun Jaringan Printer Nirkabel Menggunakan Wireless Router TL-MR3420V2 dan OpenWRT, 17(1), 14-19. https://doi.org/10.12777/TRANSMISI.17.1.14-19

Tulloh, R., Hariyani, Y. S., Hafidh, M. F., \& Pertiwi, A. W. (2017). PAPAN INFORMASI DIGITAL BERBASIS RASPBERRY PI MENGGUNAKAN JARINGAN WIRELESS DISTRIBUTION SYSTEM. SIMETRIS, $8(2), 721-730$. 